\title{
EXEGETICAL ANALYSES AND SPIRITUAL READINGS OF THE STORY OF THE ANNUNCIATION (LUKE 1:26-38)
}

\begin{abstract}
In this paper, four readings of Luke 1:26-38 are presented, together with evaluations regarding their possibilities for spirituality. The first reading is that of Lohfink. In his approach, the focus falls mainly on Jesus. Hardly any attention is accorded to the other characters: God, Gabriel and Mary. The second reading offers analyses in terms of which Mary is viewed as a prototype of liberation spirituality. This reading is informed by semiotic analysis and the sociology of literature. The third reading, which is based on narrative criticism, focuses on what happens to the characters of the story. The fourth reading is an intertextual one, which shows how the quotation of Gen 18:14 becomes an expression of one of the specific topics relating to the spirituality of the Gospel of Luke. The conclusion is that it is not the use of a specific method that is decisive for spirituality, but rather the openness of the researcher.
\end{abstract}

\section{INTRODUCTION}

The aim of this paper ${ }^{1}$ is to explore the possibilities offered by several exegetical methods for the purposes of spirituality. I will examine the story of the Annunciation (Luke 1:26-38) four times, using five methods. In each case, I will evaluate the use of the methods, as well as the results, from the perspective of spirituality. I have defined the nature of Biblical spirituality elsewhere in this volume. Proceeding from the definition of spirituality as the

1 Some parts of this paper have been published before as Welzen (2003).

Dr Huub Welzen, Research associate, Department of New Testament, University of the Free State, South Africa; Researcher in the field of Biblical Spirituality at the Titus Brandsma Institute, Nijmegen (The Netherlands). E-mail: Huub.Welzen@TitusBrandsmalnstituut.nl

Acta Theologica

2011 Suppl 15:21-36

ISSN 1015-8758

http://dx.doi.org/10.4314/actat.v31i1S.3

(C) UV/UFS

<http://www.uovs.ac.za/ActaTheologica> 
divine human relational process as transformation (Waaijman 2002), I arrive at a definition of Biblical spirituality as the divine human relational process in Biblical texts, and the Bible in the divine human relational process. In terms of the aim of this paper, this means that in the evaluation of the use of exegetical methods, attention will be focused on the question as to whether the methods that are used allow for the exploration of the divine human relational process as it appears within the text, as well as the question of how the readers of these texts can be involved in this process.

\section{A FORM-CRITICAL ANALYSIS}

In form-critical readings, it is assumed that, in addition to several concrete texts of the Old Testament, ${ }^{2}$ a number of literary forms of the Old Testament have also been worked into the story of the Annunciation. Gerhard Lohfink $(1975: 86-96)^{3}$ has provided an evocative elaboration of this aspect. The first literary form is the announcement of the birth of a child. This literary form is encountered, for instance, in the announcement to Hagar, in Gen 16:7-12, regarding the birth of Ishmael, and in the announcement to Abraham of the future birth of Isaac, in Gen 17:15-19. This literary form is typically comprised of four constitutive elements:

1. The appearance of a celestial being;

2. The announcement of the birth of a son;

3. The announcement of the name of the son;

4. The revelation of the destiny of the son.

It is easy to recognize these four elements in the first part of the story of the announcement to Mary. According to verses 26-27, Gabriel was sent by God to Mary. Verse 31a comprises the announcement of the birth of a son. In verse $31 \mathrm{~b}$, Gabriel instructs Mary to call her son Jesus. In verses 32-33, the future of Jesus is revealed.

In the second part of the story, another literary form can be discerned - namely, that of the vocation stories of the Old Testament. This form is

2 The most obvious are: "The Lord is with you", which appears almost verbatim in Ju 6,12 LXX (the article is lacking and the order of the words is reversed); "Do not be afraid", which is a typical formula in stories of the appearance of a celestial being (See Gen 15:1; Jos 8:1; Ju 6:23; Dan 10:22; Tob 12:17); "Nothing will be impossible with God", which is derived from Gen 18:14. Moreover, verses 32-33 contain many allusions to the prophecy of Nathan in 2 Sam 7:12-16.

3 In addition to the book of G. Lohfink, a workbook has appeared: Bühler, Werner and Marianne (1980). 
encountered, for instance, in the account of the calling of Moses in Ex 3:1012 , or that of the calling of the prophet Jeremiah in Jer 1:4-10. The vocation story also has four constitutive elements:
A. God speaks and imposes a vocation on a person;
B. The person who has been called voices his objections;
C. God refutes the objections by means of a more detailed explication;
D. God gives a sign to confirm his explication.

It is not difficult to recognize these constitutive elements of the Old Testament vocation story in the second part of the story of the Annunciation. The first part can be read in its entirety as a kind of calling. In verse 34, Mary expresses her objections. Gabriel then provides a further explication in verse 35. In verse 36 he informs her that Elizabeth is pregnant, and this is the sign that confirms the explication given in verse 35.

Gerhard Lohfink shows how, in the story of the Annunciation, the literary form of the announcement of the birth of a son and the literary form of the vocation story are, in fact, combined - with great artistic skill. The first element of the vocation story (God speaks and imposes a vocation on a person) is replaced by all of the elements comprising an announcement story. This results in the beautiful structure that is also present in the preceding story of the announcement to Zechariah. The total structure can be portrayed as follows:
Appearance of a celestial- being;
A. -
2. Announcement of the birth of a son;
3. Announcement of the son's name;
4. Revelation of his destiny.
B. Objections;
C. Explication that refutes the objections;
D. Sign that confirms the explication.

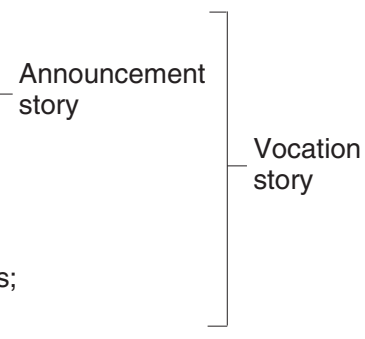

Gerhard Lohfink's argument points to verses 32-33 as the central part of the story. The most important element of the vocation story is element $A$ : the calling of a person by God. In the story of the Annunciation, it is precisely this element that is replaced by the announcement story. The most important element of the announcement story is the revelation of the future of the person whose birth is being announced: element 4 . This leads us to A4: verses 32-33. 
These verses are an expression of the significance of Jesus: "He will be great, and will be called the Son of the Most High, and the Lord God will give to him the throne of his ancestor David. He will reign over the house of Jacob forever, and of his kingdom there will be no end."

On the basis of this analysis, Gerhard Lohfink concludes that the story of the Annunciation is a Christological story, in which the confession of faith after Easter is echoed: Jesus is the son of God, Jesus is the Messiah who is exalted as a king; Jesus is the fulfilment of the promises of the Old Testament. In Lohfink's view, one could actually speak of a confession story in this regard.

It must be said that, while the result of Lohfink's analysis is a beautiful literary form, some critical points nevertheless need to be made. One is almost left with the impression that the analysis of Lohfink is determined by his polemical stance toward people who view the story of the Annunciation as a report of historical events. This is precisely why Lohfink stresses the functions of the text as a confession story and as a creed in the early Christian community (Lohfink 1975:94-96). But the matter is not quite as simple as that. Luke presents his work as history. The preface of the gospel (Luke 1:1-4) has all the characteristics of the prefaces of the historical works of his time. Of course we must not read the Gospel of Luke as a critical study resembling that of a historian of our own time. The fact that Luke presents his work as history poses a challenge to modern-day scholars to reflect the relation between history and faith in Luke-Acts. The aim of this paper is not to investigate the historicity of the story of the Annunciation. Nevertheless, it is important to realize that Luke's vision of history is linked to his spirituality - God is acting in history. One could thus ask whether Lohfink's distinction between history and faith actually does justice to the intention of the Lucan project.

Another point of criticism is that the Christological reading overlooks certain elements in the text. For instance, no attention is focused on other characters in the story besides Jesus, and no consideration is given to the significance of the dialogue between Gabriel and Mary. In particular, the salutation in verse 28 and the further explication of the angel's greeting in verses 29-30 do not feature in the analysis of Lohfink. In the third section of this paper I will provide an analysis of this dialogue, and indicate the import of the salutation from the viewpoint of spirituality.

A third point of criticism relates to Lohfink's use of form criticism. His approach is a mix of diachronic and synchronic methodology. It differs from classical form criticism, as introduced by Martin Dibelius and Rudolf Bultmann. The latter authors were searching for the simplest literary forms in the earliest stages of the Christian tradition, and their "Sitz im Leben". Lohfink's approach suggests that the form of the story of the Annunciation can be found in the text as it stands. This reflects the synchronic element in his approach. On the 
other hand, in his assertion that the confession of faith after Easter is echoed in the story, he is alluding to the stages of the tradition before Luke - and this reflects the diachronic element in his approach. Although Lohfink presents his approach as form criticism, it cannot be regarded as form criticism in the classical sense.

A fourth remark relates to the position and function of the pericope in the Gospel of Luke. As form criticism focuses only on the smallest literary units and their function and "Sitz im Leben" in early Christian community life, no attention is accorded to their position and function in the whole of a gospel. As a consequence, the role and the function of verses 32-33 in the context of the Gospel of Luke are not discussed. As I have shown elsewhere (Welzen 2008), these verses play a key role in the way Jesus is characterized as the Davidic king who, as a saviour, brings liberation and salvation to his people. It is possible to understand concepts such as "son of God" and "son of the Most High" against the background of the Old Testament traditions of the Jahvistic king. The characterization of Jesus as this Jahvistic king links up with important thematic threads, or lines, in the spirituality of Luke - lines that may be characterized as a Lucan spirituality of liberation.

The creed that is implicit in the story of the Annunciation can be described as a kind of God-relatedness. The discussion of a creed or confession of faith may comprise an occasion for speaking about spirituality (Waaijman 2002:720). But in the analysis of Lohfink, one misses the dynamic and transformational process of the divine human relationship. His analysis comes across as a static utterance about the exaltation of Christ. In his analysis, no clarity is reached on the question as to how the creed functions in the bipolarity of the text and reader, nor does it indicate how the creed functioned in the early Christian community, or how it functions in the context of the Gospel of Luke.

\section{MARY AS A PROTOTYPE OF THE SPIRITUALITY OF LIBERATION}

After his classic study of the first two chapters of the Gospel of Luke (Laurentin 1957), the great scholar in Mariology, René Laurentin, studied these texts again - this time against the background of the change of methodological paradigm that occurred in exegetical practice during the seventies and eighties of the last century (Laurentin 1982). Starting from the basic semiotic premise that meaning is the result of equivalence and difference, René Laurentin studies the literary structure in Luke 1-2, and in particular, the parallels that are found in these chapters between the stories about John the Baptist and the stories about Jesus. Within this framework, the parallels and contrasts in the stories 
of the announcement to Zechariah and the announcement to Mary are also studied in depth. The conclusion reached by Laurentin is that the parallelism is properly limited to the framework of the story. Within this framework, the contrast is a prominent factor. From the social and public point of view, Zechariah enjoys some privileges in comparison to Mary. His priesthood, his origins, and his election to enter the sanctuary endow him with honour and esteem. The angel of God appears to him in the social and religious centre of his people - the temple in Jerusalem. In contrast, Mary's origins are not mentioned. The fact that Elizabeth - who, like Zechariah, is from a priestly background - is called a relative of Mary, cannot be regarded as an indication of Mary's origins. The Greek word ouyyevis does not indicate the precise nature of the relationship. The appearance of the angel to Mary takes place in a relatively unknown town in the province. Despite her lower position in the social and public sphere, Mary is favoured and elevated above Zechariah. For instance, Zechariah is characterized according to his obedience to the law, whereas Mary is characterized according to grace. Zechariah remains passive at the moment of the appearance of the angel, whereas in Mary's case, an active inner reflection takes place. The objection of Zechariah is regarded as unbelief by the angel, whereas the response to Mary's objection is a faithful promise. At the end of the story, Zechariah is unable to speak, whereas Mary gives utterance to a declaration of faith.

In the analysis of René Laurentin, Mary is portrayed as the representative of the people who receive liberation. This liberation is reflected in the reversal of the polarities between Zechariah and Mary. In the Gospel of Luke, this reversal of polarities is one of the typical forms in which liberation is realized (see, for instance, 1:52-53; 6:20-26; 14:11 and 18:14; 16:19-31; 18:9-14).

The findings of René Laurentin are confirmed by the literary sociological investigations by Joel B. Green (Green 1992). In his commentary on the Gospel according to Luke, Green follows a similar sociological approach, which pays particular attention to the theme of status (Green 1996). The new status that Mary receives arises from an initiative of God. In the story of the Annunciation, and in her Song, she calls herself a servant of the Lord. She thereby receives, so to speak, a place in the household of the Lord. There are no indications of her status, other than the grace of God and her election by God. To understand the words of Mary in terms of their full significance, it must be realized - according to Green - that in the Greco-Roman world, the status of a servant is determined by the head of the family, the lord. The story of the announcement to Mary marks the start of a liberation which concretely consists in a violation of the social relationships of the Mediterranean world of the first century. The status of Mary is not mentioned; but she is favoured by the Lord. She becomes a model for all those who are liberated by God. 
In the analyses of Laurentin and Green, much attention is focused on the social contrast between Zechariah and Mary. But this contrast is not as absolute as they suggest. It is important to note that, in the story of Zechariah, God also takes the initiative, and that this story is also a story of liberation. Moreover, Zechariah's righteousness according to the law is approved by the narrator and by God (Luke 1:6) - his prayer has been heard (Luke 1:13-14). Thus, Laurentin's characterization of Zechariah according to his obedience to the law, as against the characterization of Mary according to grace, is not valid, since no real contrast is at issue here. In Luke 2:22-24, Mary and Joseph are also characterized according to their obedience to the law. The question arises as to whether, from a social point of view, there is really any reversal of polarities between Zechariah and Mary in the events recorded in the Gospel. The most striking aspect of the composition of Luke 1-2 is the parallelism between the narrative about John and the narrative about Jesus. If there is any contrast, it is a contrast within the parallelism. The reason for this contrast is not the difference between Zechariah and Mary, but rather the difference between John and Jesus. John is a prophet of the Most High, whereas Jesus is the son of the Most High. The question that arises is that of whether the contrast in these stories is actually a contrast from a social point of view. Perhaps the fundamental transformation in these stories does not pertain to the social transformation of the characters, but rather to a transformation in the reader from a social point of view to a spiritual-theological point of view. If so, the transformation in the point of view of the reader implies a change in the evaluation of the positions of Zechariah and Mary.

From the perspective of spirituality, semiotic and literary sociological analyses like those of René Laurentin and Joel B. Green offer many advantages. The text of the Annunciation is not regarded as an isolated literary unit. The analyses of both René Laurentin and Joel B. Green are open to important themes of the spirituality of the Gospel of Luke as a whole: themes such as the initiative of God, the liberating action of Jesus, and the theme of wealth and poverty. It is also important to note that, in their analyses, it becomes very clear that God plays an active role in the story. It is because of God's initiative that Mary is elevated above Zechariah. It is owing to his initiative that she acquires a new status. Because spirituality is about the divine human relational process, one must not overlook this divine initiative.

In their analyses, attention is also focused on the impact of this divine initiative on the human situation. Mary is an example of the Lord's exaltation of humiliated people, which is a central theme in the spirituality of Luke. And-last but not least - analyses like those of René Laurentin and Joel B. Green offer possibilities for oppressed people to identify with Mary. In particular, women who are oppressed in the church and in society are fortified by the story of 
the Annunciation. One can see the impact of the story even on present-day readers.

\section{THE DIALOGUE OF GABRIEL AND MARY: NARRATIVE CRITICISM}

As a starting point for a third reading, we will adopt a narrative critical approach in which attention is accorded to the events in the story, and in conjunction therewith, to the verbs which indicate actions. Of course, the verbs contained in the direct and indirect speech are excluded. There are

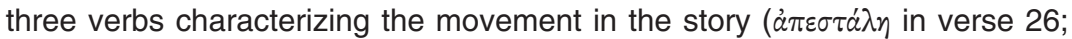
$\varepsilon i \sigma \varepsilon \lambda \theta \dot{\omega} \nu$ in verse 28 and $\dot{a} \pi \tilde{\eta} \lambda \theta \varepsilon v$ in verse 38 ); two verbs indicate feelings and

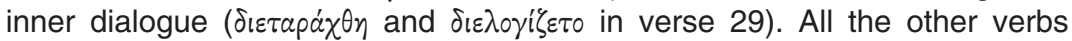
function within the dialogue between Gabriel and Mary ( $\varepsilon i \tilde{i} \pi \varepsilon v$ in verses 28, 30,

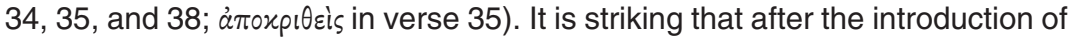
the acting characters in the story (God, Gabriel and Mary), a chiastic structure follows. In this chiastic structure, God disappears as an acting character. The extreme poles of this sandwich structure are formed by the movements of coming in ( $\varepsilon \dot{i} \sigma \varepsilon \lambda \theta \dot{\omega} \nu$ in verse 28$)$ and departing ( $\dot{\alpha} \pi \tilde{\eta} \lambda \theta \varepsilon v$ in verse 38). Within these two poles, the communication between Gabriel and Mary takes place. The salutation of Gabriel and the eventual response of Mary are related to each other. The centre of the sandwich structure is formed by a double structure of question and answer. The question as to what kind of salutation the words of the angel might be (verse 29) receives an answer in verses 30-33. In verse 34 , a new question arises, which is answered in verses 35-37. The question as to how this can be receives an appropriate answer in the reassurance of the angel that nothing will be impossible for the Lord. It is important to note that, within the analysis of the dialogue of Gabriel and Mary, God is the proper initiator of the events, although he is not an active participant in this dialogue. Because God is the initiator, Frans Mussner calls him the real actor of the whole story (Musser 1942), but God does not participate in the dialogue. By sending the angel Gabriel, God initiates the events of the story and makes them possible.

Furthermore, it is important to realize how the two questions refer to preceding words and actions. The question in verse 29 relates to the meaning of the foregoing salutation by the angel. This implies that verses 30-33 can be read as a more detailed explanation of this salutation. The way in which the 
question asked by Mary in verse 34 refers to the preceding words is important too. She asks how what has just been said can come about. ${ }^{4}$ This question receives an answer in verses 35-37. In other words: the double structure of question and answer is linked to the salutation of the angel. It comprises a further explanation of the greeting, leading to Mary's reaction to the salutation, which follows in verse 38. From a communicative viewpoint, the culminating point of the story is the announcement of the angel: "Rejoice, favoured one! The Lord is with you," and the eventual reaction of Mary to this announcement: "Here am I, the servant of the Lord; let it be with me according to your word." The narrative structure can now be portrayed as follows:

A

B

C

D Question regarding the meaning of the salutation: verse 29

D' Answer of the angel: verses 30-33

E Question as to how this can be: verse 34

E' Answer of the angel: verses 35-37

C' Reaction of Mary: verse $38 \mathrm{a}$

B'

The two main elements of this communication can be indicated as the address and the dedication. Both elements will now be briefly discussed. The

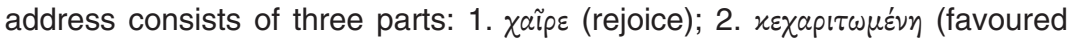
one); 3. $\delta$ xúplos $\mu \varepsilon \tau \dot{\alpha}$ бou (the Lord is with you). In this address the tone of joy is predominant. Xaĩpe is not only a salutation; it is also an expression of joy. The root of the word is repeated in the following context, in the second part of the salutation: $x \varepsilon \chi \alpha \rho i \tau \omega \mu \varepsilon \dot{v} \eta$ (Conzelmann 1990). In addition, the root appears again in verse 30 , in which the angel explains the meaning of the salutation:

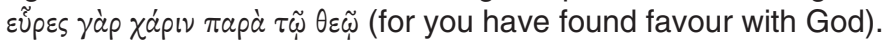

In two articles, Ignace de la Potterie (1987a, 1987b) discusses the meaning of the word $x \varepsilon \chi \alpha \rho i \tau \omega \mu \varepsilon \dot{v} \eta$. He points out two traditions of interpretation. In the Protestant tradition, the word indicates the grace received by Mary at the moment of the announcement. It is the grace of future motherhood, based on election by God. Ignace de la Potterie endorses the Roman Catholic tradition. In this tradition, the word $x \varepsilon \chi \alpha \rho i \tau \omega \mu \varepsilon v \eta$ indicates the situation in which Mary already finds herself at the moment of the announcement. One of the most

$4 \quad$ Much has been written concerning the question as to whether the objection of Mary and the response to this objection pertain to virginal conception and virginal birth or not. See, for instance, the debate in recent scholarship: Brown $(1971,1974)$, Fitzmyer (1973), Schaberg (1987), Landry. 
important arguments is that $\chi \varepsilon \chi \alpha \rho i \tau \omega \mu \varepsilon \dot{v} \eta$ is a participle in the perfect tense; this means that it refers to an event in the past that has an impact extending up to the present. For the purposes of our discussion, it is even more important that this participle is in the passive voice, and can be understood as a divine passive. This means that it refers to an initiative of God's grace, which has a transformative impact on the life of Mary. Consequently, Ignace de la Potterie interprets the address of the angel as follows: "Rejoice, you who are transformed by God's grace." The fact that the participle is a divine passive is confirmed by Gabriel's explanation in verse 30: "You have found favour with God." Because of the frequency of the root, $\chi \alpha$ pis, the factor of gratuitousness cannot be overemphasized. God's favour is gratia gratis data.

The reaction of Mary to the offer of grace from God follows in verse 38. A new identity has come into being: an identity in relation to God: "Here am I, the servant of the Lord." Luke attests to the truth of the fact that this identity entails a total commitment. "No servant can serve two masters," according to 16:13. The new identity reflects a surrender to the future that the word of God will bring to Mary: "Let it be with me according to your word."

This third reading of the story of the Annunciation shows that, in the mystical journey of Mary, something occurs that is similar to what happens in the life path of Jesus. In the third chapter of the Gospel of Luke, in the story of the baptism of Jesus, God reveals himself as the father of Jesus. The words uttered by the voice from heaven are highly affective in character. Jesus is addressed in terms of his identity: "You are my beloved son. With you I am pleased." (3:22) This address from heaven is comparable to the angel's address to Mary: "Rejoice, favoured one. The Lord is with you." On the night before his death, Jesus prays: "Father, if you are willing, remove this cup from me; yet not my will but yours be done." (22:42) This surrender is essentially the same as the surrender of Mary in 1:38. In other words: in the case of Mary, for the description of the mystical journey - starting from the divine address, followed by transformation and the finding of a new identity, until the mystical surrender - Luke needs just one pericope. In the case of Jesus, an entire book is required for this description. The latter comparison may admittedly be perceived as an overstatement. Indeed, a nuanced description would be required in order to trace the mystical journey of Mary in comparison to the mystical journey of Jesus in the Gospel of Luke. But the similarity in the process is striking.

The story of the Annunciation offers a perfect opportunity to bridge the gap between the communication of the characters in the story and the communication of the narrator and the reader. To demonstrate this, we will use the typology of narratives presented by Hugh C. White (1991) in his book about Genesis. There are three types of narratives. In the first type, the voice of the narrator is dominant. Narratives with an all-knowing narrator - that is, a 
narrator who knows what the characters are thinking, as well as the motives for their actions - belong to this type. In all aspects, the narrator dominates the story. This type of narrative is characterized by indirect speech. In the second type, the narrator is absent. The dialogue of the characters is a typical feature of stories belonging to this type. There is no narrator who reports what the characters are thinking, or explains the motives for their actions. This type of narrative is characterized by direct speech. The third type is a combination of the first and second types. This third type is characterized by free indirect speech. The voice of the narrator is present in the voice of the character and vice versa. For the reader/hearer of the story, it is often difficult to decide whether he is hearing the voice of the narrator or that of the character. ${ }^{5}$

From the perspective of this typology, the question in verse 29 is very interesting. Whose voice are we hearing? Is it the inner voice of Mary, wondering what sort of greeting the salutation of the angel might be? Or is it the voice of the narrator, communicating with his readers by revealing Mary's inner questioning of the possible meaning of Gabriel's salutation? I would say that, since the question is rendered in indirect speech, we are hearing the voice of the narrator. ${ }^{6}$ Verse 29 is the only part of the text in which the communication of the characters is reproduced in the indirect mode as a communication of the narrator to his readers. He conveys to his readers what Mary is thinking. This communication to the readers makes it possible for them to enter the story and to participate in the process of the story.

On the basis of the foregoing, we may conclude that narrative criticism offers useful tools for the description and articulation of the spiritual process in the text. In paying attention to the events and transformations in the story, distinct possibilities arise for the description and articulation of the transformational aspects of the divine human relational process. The analysis of the way in which the narrator communicates with his readers also provides us with the necessary tools to describe and articulate the way in which the gap between the events in the story and the readers is bridged. Aspects that are important for this kind of analysis include the use of different voices; evaluations of the narrator and the characters; descriptions of situations; evaluations, focalizations and points of view; the organization of time and space; the use of gaps, and narrative commentary, inter alia.

5 As a technique in telling novels, free indirect speech was introduced in the $19^{\text {th }}$ century (Luxemburg, Bal, Wetsteyn 1982:135-136).

6 The optative हln should be regarded as an optativus obliquus (Blass \& Debrunner 1970:386, 235). 


\section{INTERTEXTUALITY: GEN 18:14 AND LUKE 1:37}

In the fourth reading of the story of the Annunciation, I will show how echoes from other stories become part of some of the fundamental spiritual premises in the Gospel of Luke, and may perhaps have contributed to the genesis of these basic spiritual premises. My discussion is restricted to the way in which Gen 18:14 elucidates some aspects of the Lucan theme of poverty and wealth, making this theme a spiritual theme.

Gen 18:1-15 is the story of the appearance of the Lord to Abraham near the oak of Mamre. In this story, the Lord tells Abraham that Sarah will have a son. An account is given of how Sarah listened at the tent entrance behind Abraham and laughed to herself, because Abraham and Sarah were in their old age. And the Lord said to Abraham: "Why did Sarah laugh, and say, 'Shall I indeed bear a child, now that I am old?' Nothing is impossible with the Lord."

Like the story of the visit of Gabriel to Mary, this story is an announcement story. In actual fact, Gen 18:1-15 contains more similarities to the story of Zechariah and Elizabeth than to the story of the Annunciation, because of the old age of Abraham and Sarah (cf. Luke 1:7). ${ }^{7}$ Therefore, in this story the echoes of Gen 18:14 are to be expected. Yet in Luke 1:37, Gabriel uses the same words that the Lord used in Gen 18:14. In Luke 1, the echo of Gen 18:14 serves to underscore the cumulation of the impossibility (since the event predicted by Gabriel in the Annunciation to Mary seems to comprise an even greater impossibility than the event predicted by him in the announcement to Zechariah). The impossibility for Abraham and Sarah - and for Zechariah and Elizabeth - was the notion that God could send a child to an aged couple, and particularly a barren woman. For Mary, the point of the reference to Gen 18:115 is that if God can do this, then he can also do the impossible in her case, although she is a virgin.

Both the story of Abraham and Sarah and the story of Mary are about a future event that is impossible in human terms. This is why Sarah laughed; and it is also the reason why Mary asks how this can be. The answer of the Lord and the answer of the angel is that nothing is impossible for the Lord. Although the wording of Luke 1:37 is based on Gen 18:14 (LXX), it is not exactly the same:

Gen 18: $14(L X X): \quad \quad \mu \grave{n} a ̉ \delta u \nu a \tau \varepsilon \tilde{~} \pi \alpha \rho \dot{\alpha} \tau \tilde{\omega} \theta \varepsilon \tilde{\omega} \dot{\rho} \tilde{\eta} \mu \alpha$

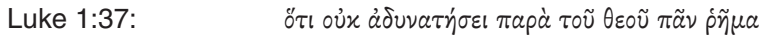

7 Green (1997:52-55) gives a survey of the points of correspondence of the Abrahamic material of Gen 11-21 and Luke 1:5-2:52. 
The words fit into the story of the Annunciation very well. The word $\dot{p} \tilde{\eta} \mu \alpha$

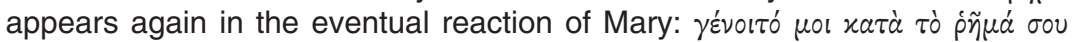
(1:38). The root of the word, $\dot{\alpha} \delta \cup v a \tau \eta^{\prime} \sigma \varepsilon l$, also appears in the context. Earlier on, in his answer to Mary's question as to how all this might come about, Gabriel

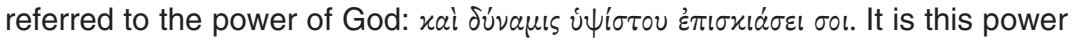
that makes impossible things possible. God's power gives a future where people do not expect it: for Mary, for Elizabeth, for Abraham and Sarah.

The root appears again in the Song of Mary that follows (1:46-56). In her song, Mary calls God by four names: xúplos, $\theta$ zós, $\sigma \omega \tau \eta^{\prime} \rho$ and $\delta$ duvatós. It is the name $\delta$ duvatós that warrants our attention in this regard. It refers to the Mighty One who has done great things for Mary. A beautiful play on words is found in the Song of Mary. In the second, eschatological part of the song, it is declared

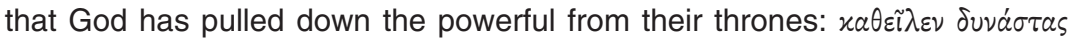

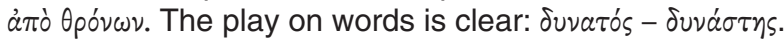

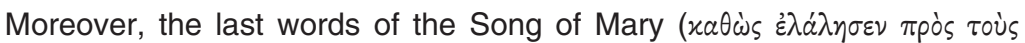

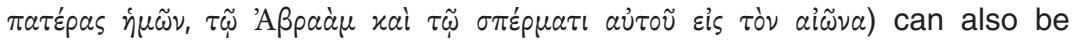
understood as an echo of Gen 18:15. The appearance of the words $\dot{\varepsilon} \lambda \dot{\alpha} \lambda \eta \eta \varepsilon \nu$,

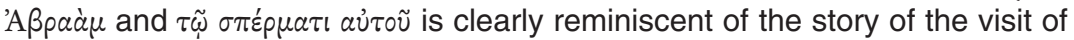
the Lord to Abraham: a story in which God makes possible what is impossible in the view of human beings. Both are stories in which God grants a future that is not expected or anticipated by people.

At the same time, in the Song of Mary, the power of God is linked to the theme of the reversal of social polarities, which comprises a prominent theme in the Gospel of Luke (see also 6:20-26; 14:11; 16:19-31; 18:9-14). In this reversal, it becomes clearly evident that God is the Mighty One. He - and not those who are powerful in this world - is the master of our future. It is not human beings who have the power to determine our future. God's future is not made by men: it is a future granted by Him - free of charge. It is as if we are

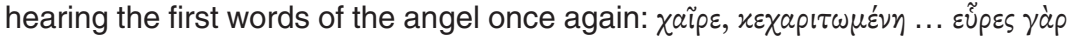

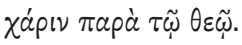

It is important to realize that a granted future has two sides: firstly, the future is given by God; and secondly, human beings cannot control their future. The first aspect is illustrated in the story of the Annunciation and the Song of Mary. The second aspect is not absent from the Gospel of Luke. It is illustrated, for instance, in the parable of the rich fool (12:13-21). ${ }^{8}$ The harvest of a rich man gave him the opportunity to provide for his future. "What should I do?" he asked. Then he decided: "This is what I will do: I will pull down my barns and build bigger ones, and store all my grains and my goods in them, and I will say to my soul: My soul, you have plenty of good things laid by for many years to

8 For a more detailed discussion, see Welzen (1987). 
come; take things easy, eat, drink, have a good time." The end of the story makes it clear how foolish it is to try to retain control over our future.

The story of the Annunciation and, more especially, the way in which Gabriel's assertion that nothing is impossible with God is embedded in the text, show how Luke's reading of Gen 18:1-15 contributes to a spirituality in which the Lord is $\delta$ duvatós. The Lord is the initiator of the future of all those who surrender themselves to the future that God grants. The opposite attitude is that of the powerful, who believe that they can control their lives. In the spirituality of the Gospel of Luke, this opposite attitude is the attitude of fools: "You fool! This very night your life is demanded of you." (12:20)

One question remains: Is it the spirituality present in the Gospel of Luke that originally gave rise to the reading of Gen 18:1-15 in such a way that it fits into the context of the Annunciation? Thus, is it a case of pre-understanding? Or did the reading of Gen 18:1-15 contribute to the birth of this specific spirituality in the Gospel of Luke? In the latter case, we may regard this spirituality in the Gospel of Luke as the result - and impact - of a spiritual reading process in respect of Gen 18:1-15. Perhaps both possibilities are valid. If so, we have an example of the circular interactive process in which a reader attributes meaning to the text, while at the same time, the text has a transforming impact on the reader.

\section{CONCLUSION}

In this paper, four readings of the story of the Annunciation were presented. Five approaches were used: form criticism, semiotics, sociology of literature, narrative criticism, and intertextuality. As a conclusion, it can be said that there is no clear-cut distinction between exegetical analyses and spiritual readings. All the exegetical tools that were used in this paper can be effectively applied for the analysis of the spirituality in the text, or of the spiritual process that occurs between text and reader. The answer to the question as to which method is the most appropriate depends on the nature of the question that is posed. A form-critical question is not the same as a narrative-critical question, or a question pertaining to intertextuality. But if an openness to the divine human relational process is present in the way the questions are posed, all the questions and all the answers may offer possibilities for the purposes of spirituality. In my view, this is the most decisive aspect: the researcher's openness to the process of spirituality - both in terms of the text itself, and of the impact of the text on the divine human relationship of the reader. 


\section{BIBLIOGRAPHY}

Blass, F. \& Debrunner, A.

1970. Grammatik des neutestamentlichen Griechisch. Göttingen: Vandenhoeck \& Ruprecht.

BRown, R.E.

1971. The Problem of the Virginal Conception of Jesus. Theological Studies 33: 3-34.

1974. Luke's Description of the Virginal Conception. Theological Studies 35: 360-362.

BüHLER, WeRner \& MARIANNE

1980. Leren lezen achter de woorden. Werkboek bij "lezen achter de woorden" van Gerhard Lohfink. Brugge: Emmaüs, Boxtel: Katholieke Bijbelstichting. (Translation of: Die Bibel verstehen.)

Conzelmann, $\mathrm{H}$.

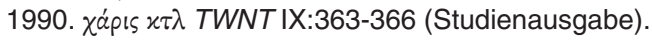

De la Potterie, I.

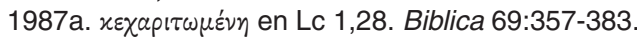

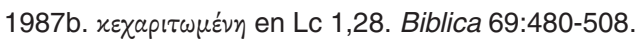

FITZMYER, J.A.

1973. The Virginal Conception of Jesus in the New Testament. Theological Studies 34:541-575.

Green, J. B.

1992. The Social Status of Mary in Lk 1,5-2,52: A Plea for Methodological Integration. Biblica 73:457-472.

1997. The Gospel of Luke. Grand Rapids, Michigan, Cambridge: William B. Eerdmans Publishing Company.

LANDRY, D.T.

n.d. Narrative Logic in the Annunciation to Mary (Luke 1:26-38). [Online] Retrieved from http://personal1.stthomas.edu/dtlandry/mary.html

LAURENTIN, R.

1957. Structure et Théologie de Luc I-II. Paris: Gabalda.

1982. Les Évangiles de l' Enfance du Christ. Verité de Noël au-dela des mythes. Exégèse et sémiotique. Historicité et théologie. Paris: Desclée: Desclée de Brouwer.

LOHFINK, G.

1975. Lezen achter de woorden. Literaire vormen in de bijbel. Brugge: Emmaüs, Boxtel: Katholieke Bijbelstichting. (Translation of: Jetzt verstehe ich die Bibel.) 
MUSSNER, Fr.

1942. Das „Semantische Universum“ der Verkundigungsperiokope (Lk 1,26-38). Catholica 46:228-239.

SCHABERG, J.

1987. The Illegitimacy of Jesus: A Feminist Theological Interpretation of the Infancy Narratives. San Francisco: Harper \& Row.

Van Luxemburg, J.; Bal, M. \& Wetsteyn, W.G.

1982. Inleiding in de literatuurwetenschap. Muiderberg: Coutinho.

WAAIJMAN, K.

2002. Spirituality. Forms, Foundations, Methods. Leuven - Paris - Dudley (MA): Peeters.

WELZEN, H. 1987. De parabel van de rijke boer (LC 12,13-21). In: B. van lersel, T. van Schaik, S. van Tilborg, H. Welzen \& W. Weren (eds.), Parabelverhalen in Lucas. Van semiotiek naar pragmatiek, (Tilburg: Tilburg University Press (=TFT studies 8)), pp. 83-109.

2003. Maria als model voor de mystieke weg. Interpretatie 11 (1):26-28.

2008. "Were not our hearts burning within us while he was talking to us on the road, while he was opening the Scriptures for us?" (Luke 24:32). Spiritual Hermeneutics as a Heuristic Model for the Spiritual Aspects of Intertextuality within the Lucan Corpus. In: H. Blommestijn, C. Caspers, R. Hofman, F. Mertens, P. Nissen \& H. Welzen (eds), Seeing the Seeker. Explorations in the Discipline of Spirituality. A Festschrift for Kees Waaijman on the occasion of his 65th birthday (Leuven - Paris - Dudley (MA)), pp. 169- 197.

WhITE, H.C.

1991. Narration and Discourse the Book of Genesis. Cambridge, New York: Cambridge University Press.

Keywords:

Biblical spirituality

Exegetical methods

Annunciation (Luke 1:26-38)

Gospel of Luke
Trefwoorde:

Bybelse spiritualiteit

Eksegetiese metodes

Annunsiasie (Luk 1:26-38)

Evangelie volgens Lukas 